\title{
Adult Brain Stem Astrocytoma
}

National Cancer Institute

\section{Source}

National Cancer Institute. Adult Brain Stem Astrocytoma. NCI Thesaurus. Code C6954.

An astrocytoma of the brain stem that occurs during adulthood. 